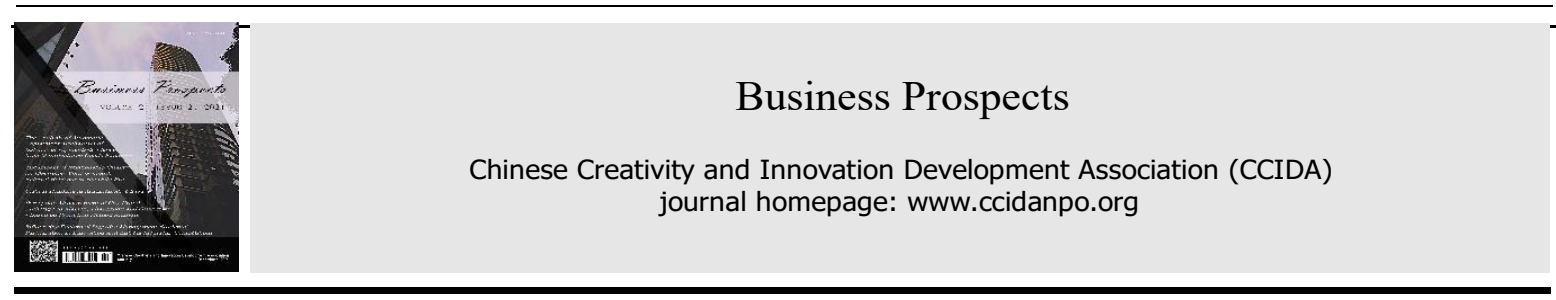

https://doi.org/10.52288/bp.27089851.2021.12.15

\title{
Research on the Influence of Different Types of Exhibition on the Development of County Economy
}

\author{
Yu-Xin Ke ${ }^{1, *}$ \\ ${ }^{1}$ School of International Business, Xiamen University Tan Kah Kee College \\ * Correspondence: adorablepoppy@126.com
}

Received: 2021.06.08; Accepted: 2021.08.10; Published: 2021.12.01

\begin{abstract}
The county-level exhibition economy is an industrial economy with the characteristics of region, feature, service and opening which takes the county as the geographical space, the county-level political power as the important impetus, the market as the direction, the exhibition and the festival activity as the core. This paper introduces six types of county-level MICE economy, and analyzes their characteristics while giving some examples of corresponding county-level or city-level exhibition. The urban exhibition competitiveness index in 2018 and 2019 is evaluated by regression analysis to develop the MICE industry more effectively as well as to promote the economic development and the prosperity of the exhibition industry of China.
\end{abstract}

Keywords: County-level MICE Economic Types; Urban Exhibition Competitiveness Index; The Development of MICE economy

\section{Foreword}

The first thing to promote the development of county economy by convention and exhibition (MICE) is to comprehend the meaning of MICE. The MICE industry has an industry-driven effect of 1:9, that is, if the direct income of the exhibition industry is 1, its driving income for transportation, tourism, catering, accommodation, and other related industries is 9 (Luo et al., 2011). As a new field of tertiary sector of the economy industry, MICE industry has irreplaceable economic functions, including linking and trading functions, integrating marketing functions, regulating supply and demand functions, the functions of technology diffusion, industry linkage and economic integration $(\mathrm{Ni}, 2021)$. With the continuous optimization and upgrading of Chinese urban economic structure, the position of MICE industry in economic development is becoming more and more important. Today, the MICE industry is more developed in Beijing, Shanghai, Guangzhou as the center of the three major cities of large and medium-sized cities and inland provincial capitals. The MICE industry has an obvious driving effect on the economic development of large cities. The driving force for small and medium-sized cities and even county economies, however, cannot be underestimated.

With the rapid development of county urbanization and the constant adjustment of industrial structure, the economic benefits brought by county-level MICE industry are more prominent. County-level MICE is an important part of Chinese MICE economy. County area is the basic link of Chinese economic development as well as the source of various types of industrial development. To this end, part of the market of MICE industry will be turned to county areas in the process of service industry development and Chinese MICE industry market environment will show the development situation of mutual complement between city and county (Wang, 2021). The brand effect of county-level MICE can rapidly promote the regional popularity, improve the county-level industrial structure, fuel the quality of resident's life, and promote the balanced and coordinated development of Chinese regional economy (Chen, 2019). However, the number, scale and grade of exhibition need to be further improved. The exhibition venues lack space to accommodate, and the management mechanism needs to be further optimized. All the above are the current difficulties and challenges that county-level MICE economic development must face (Zhang, 2021).

This study starts with the general characteristics and categories of the exhibition. In view of the particularity of the county exhibition economy, county-level exhibition economy-related indicators from 2018 
to 2019 are collected adopting multi-regression model to analyze the effects of number of exhibitions, total exhibition area and comprehensive index on the county economy to assist the county-level exhibition industry sorting out its own advantages and to establish a new trend of county exhibition development.

\section{Features of MICE}

The features of MICE are various and obvious. The comprehensiveness of the exhibition reflects in three aspects: the content of the activity, the purpose and nature of the activities, and the industries and sectors that involved. There are not only various industrial sectors of the national economy, including the primary, secondary and tertiary industries, but also non-industrial sectors, such as administration, culture, education, and social organizations. For example, the managements of the Chinese Luoyang Peony Culture Festival involve political, economic, and cultural departments. Each of them charges difference parts while each of parts line closely with each other.

Innovation is the soul of modern MICE industry. The exhibition is an important stage for new products, new technology and new information to appear in the world. The exhibition will have no vitality and lose its due attraction without innovation. The innovation makes activities to be a mirror reflecting the latest developments of all works of life and innovation forums or conferences are always essential flesh blood of whole industries.

One of the most prominent features of the exhibition activities is the concentration of the flow of people, goods, and information. The exhibition activities will be many people, products, technology, and information in a specific geographical space at a certain time. Concentration of factors of production can improve the efficiency of resource utilization and result in cost savings, increases in income or utility as of economies of agglomeration.

The innovation of science and technology plays an important role in the rise and development of MICE. Without the support of science and technology, there would be no glory of modern MICE. For example, the facilities in the exhibition hall all depend on the advanced technology. The development of science and technology also makes people see a wonderful exhibition art world.

Although the development of MICE activities will be affected by political, economic, social, natural, and other factors, there will be short-term fluctuations. But due to its mostly official nature, and has a strong planning and will not easily change, the development process is much less volatility. Compared with other industries, the MICE industry has a stronger ability to withstand economic fluctuations, which is also a major reason for its attention.

The geographical and economic distribution of MICE activities is extremely uneven, and the development of MICE varies greatly from region to region. International MICE activities in the regional performance of two kinds of concentration: one is concentrated in the developed countries and the other is in the geographical distribution in Europe and the United States. Judging from the regional distribution of international MICE activities, the developed countries in Europe and America have always been in the forefront of development.

Although different types of exhibition activities have their own characteristics in time selection, overall speaking, the exhibition activities have obvious balance in time distribution. This is mainly because the MICE activities work for the purpose, generally according to the actual needs of the organization and less affected by other factors (such as climate conditions).

The characteristics of the exhibition is very comprehensive and exhibition activities can affect society, politics, economy, culture, and environment in many ways. As a result, the impact of the universality of the development of the exhibition is very influential. In a word, MICE can promote the progress of industry and drive the better development of national economy.

\section{Classification of County-level MICE Development}

There are many kinds of MICE types, according to the types of industry, which can be divided into agricultural exhibition, light industry exhibition, heavy industry exhibition, service industry exhibition and regional characteristics industry exhibition. But according to the core of the MICE, this paper divides the county-level MICE economies into six types, and analyzes the impact of different county-level MICE types on the economy by illustrating some representative counties in China (Chen, 2019). 


\subsection{Promoting the Development of Local Industries with Local Advantages Supported by Natural Resources}

Shouguang is a county in Shandong Province, with the largest vegetable wholesale market in China. The Chinese (Shouguang) International Vegetable Science and Technology Fair was established in 2000. In 2018, the 19th Vegetable Expo, with the theme of Green, Science and Technology in the Future and supported by modern agriculture, created a comprehensive agricultural exhibition and exchange platform.

Nan'an of Fujian province, with the advantages of stone production areas and distribution centers, has gradually stepped out of an industrial development with positive interaction, which is theme of market, industry, base, and exhibition. Since 2005, the annual Nan'an Shuitou Stone Fair has had a remarkable trade effect.

\subsection{Driving Market Expansion through Professional Products}

Yuyao, a county-level city of Zhejiang Privince, has the largest professional market of plastic products and raw materials. On this basis, Chinese (Yuyao) International Plastics Fair, as well as Plastic Expo, since 1999 has been successfully held for 20 times. Yuyao has also become the world's plastic raw materials distribution and price center.

Keqiao of Zhejiang Province, formerly known as the largest cloth distribution center in Asia-China Textile City and Professional Textile Exhibition Center. Since its establishment 20 years ago, Keqiao International Textile Fair in Shaoxing has become one of the three well-known fabric exhibitions in China along with Shanghai Fabric Fair and Fabric Fair of Canton Fair.

Zhengding is the key industry supporting project of Hebei Province. Zhengding International Commodity Hall is an effective carrier for optimizing the layout of the service industry in the provincial capital. Various exhibitions in Zhengding are mainly around the small commodities, there are Shijiazhuang (Zhengding) International Commodities Fair, Tea Fair, Autumn Food Fair, Furniture Fair, Health Products Fair and so on. These exhibitions provide the economic development of Zhengding a new vitality. Among the various exhibitions, Zhengding Small Commodity Fair is relatively outstanding. As of October 2021, this fair has been successfully held for 14 times, Tea Fair for 12 times, Golden Autumn Food Fair for 12 times and Furniture Fair for 14 times, Health Products Fair for 12 times, all kinds of exhibition are basically held once a year. The exhibition economy of Zhengding is driven by a variety of professional products, and the development of the exhibition has increased the number of suppliers to produce its professional products and expanded the commodity market (Zhao and Lu, 2017).

\subsection{Servicing Manufacture with the Entire Industry Linkage}

Yongkang is in the Zhejiang Province. The craftsman spirit laid the foundation of Yongkang exhibition economy, and its hardware industry is the main body. The mature hardware industry and the huge market causes the prosperity of exhibition industry. Simultaneously, a batch of emerge from the hardware industry feeds back the exhibition. Yongkang have become well-known exhibitions both nationally and globally, and have accumulated rich experience in the operation of exhibitions through gathering the massive specialized dealer and the customer resources for each kind of product marketing promotion. The development of entity hardware industry in Yongkang has greatly driven the development of its exhibition economy.

Wenling of Zhejiang Province own more than 3,000 enterprises of water pump and electromechanical device. Since 2006, Chinese (Wenling) Water Pump and Electromechanical Device Fair had been held every year. There were more than 500 enterprises attended with more than 25 thousand of attendees, including more than 600 of them came from other 20 countries, and bringing nearly 1.5 billion of overturn. This Fair was planned to be held in Chongqing to expand more activities outside the county in 2019.

\subsection{Promoting Industrial Development Based on History and Culture}

The most wonderful flowers in Luoyang are the peony, a sign of prosperity. The peony is called the king of flowers and is the national flower of China. Luoyang has made full use of the power of science and technology to cultivate new varieties of peonies. It also researches and develops the ornamental, economic and ecological values of peonies. Therefore, Luoyang is visited from March to May every year with appreciation that become one of the essential tourist activities for tourists (Sui, 2020).

Since 2011, the Luoyang Peony Fair in Henan Province has been upgraded to a national festival and renamed as the Chinese Luoyang Peony Culture Festival. Since 1983, the festival has been held for 38th intangible cultural heritage. There are many cultural activities during the Peony Culture Festival. For example, 
Hundreds Legend During Sui and Tang Dynasties, Heluo Style Performance Month, Eight Li Tang Heluo Culture Collection, Nine Volumes of Kungfu Poetry, Wu Zetian, Luoshen, and other large-scale tourism performances and programs fascinating, which are never tired of being watched. It is an effective way to carry forward the Chinese traditional culture in the festival activities.

\subsection{Enhancing the Development of MICE with Brand Consciousness}

Guzhen of Guangdong Province, is famous throughout the country for its lighting exhibitions. The 22nd Chinese Guzhen International Lighting Fair was held from 22 to 26 October 2018 at the Guzhen Convention and Exhibition Center, in conjunction with the International Lighting Culture Festival. Therefore, the popularity and influence of Guzhen have been rising a lot.

Anping of Hebei Province, is the capital and industry base of Chinese silk named by the Chinese Hardware Products Association. The Chinese Anping International Silk Screen Fair, hosted by the government of Anping, is the only professional silk screen fair all over the world. It has been held eighteen times since 2001 and has become a new bright spot in the development of the county exhibition economy.

\subsection{Developing Incentive Tourism while Launching Innovation Conference}

Kubuqi of Inner Mongolia Ordos City is a town-level county. Since 2007, Kubuqi International Desert Forum was held there twice a year for 7 times. In February 2014, the Chinese government regarded Kubuqi International Desert Forum as a national mechanism for large foreign-related forums. In July 2017, general secretary Xi Jinping sent a congratulatory letter to the 6th Kubuqi International Desert Forum, and this forum was approved to be an essential platform of interacting the experience of sand-fighting and promoting the achievement of the goal of sustainability the UN formed for 2030.

Yabuli of Heilongjiang Province began to hold China Entrepreneurs Forum since 2001. Jack Ma, Liu Chuanzhi and other well-known entrepreneurs have been actively participating in the forum activities. In recent years, the China Entrepreneurs Forum has also chosen other cities to host its summer sessions.

Both the Kubuqi desert and Yabuli were formerly economically backward regions. These international innovation forums can attract visitors to participate in the events, promoting the development of local tourism through the incentive tourism, and make it become a characteristic type of the county MICE economic development.

\section{Analyzing the Influence Factors of the Urban Exhibition Competitiveness Index of 2018 and 2019}

Based on the definition of the six economic types of county MICE, this paper evaluates the Urban Exhibition Competitiveness Index from three aspects: numbers of exhibitions, total exhibition area, and composite index according to the data of 2018 and 2019 in order to adapt proper types of economic development for different cities.

In 2018, the average GDP of cities was 443.777 billion, with the highest GDP of 3,601.180 billion in Shanghai; the average number of exhibitions was 38.04, with the largest number of exhibitions in Shanghai is 623 ; and the average total exhibition area was 732,800 square meters, with the biggest size in Shanghai is 17.6 million square meters; the average composite index is 20.43, with the highest is 478.48 (Table 1). In 2019, the city average GDP was 4,325.18, the average number of exhibitions was 34.58 , the average total exhibition area was 630,900 square meters, and the average comprehensive index was 18.06 (Table 2). Comparison of the data of the two years shows that the latter is lower than the front.

Table 1. Descriptive statistics of urban exhibition competitiveness in 2018.

\begin{tabular}{ccccc}
\hline & $\begin{array}{c}\text { GDP } \\
\text { (one hundred million RMB) }\end{array}$ & $\begin{array}{c}\text { Number of } \\
\text { exhibitions }\end{array}$ & $\begin{array}{c}\text { Total exhibition } \\
\text { area }\end{array}$ & $\begin{array}{c}\text { Composite } \\
\text { Index }\end{array}$ \\
\hline Mean & $4,437.77$ & 38.04 & 73.28 & 20.43 \\
Standard deviation & $5,593.01$ & 73.17 & 181.31 & 52.77 \\
Minimum & 173.50 & 1 & 1 & 0.15 \\
Maximum & $36,011.80$ & 623 & $1,760.00$ & 478.48 \\
Number & 153 & 153 & 153 & 153 \\
\hline
\end{tabular}

Source: Chinese Exhibition Economic Report in 2018 and 2019 
Table 2. Descriptive statistics of urban exhibition competitiveness in 2019.

\begin{tabular}{ccccc}
\hline & $\begin{array}{c}\text { GDP } \\
\text { (one hundred million RMB) }\end{array}$ & $\begin{array}{c}\text { Number of } \\
\text { exhibitions }\end{array}$ & $\begin{array}{c}\text { Total exhibition } \\
\text { area }\end{array}$ & $\begin{array}{c}\text { Composite } \\
\text { Index }\end{array}$ \\
\hline Mean & $4,325.18$ & 34.58 & 63.09 & 18.06 \\
Standard deviation & $5,691.37$ & 66.76 & 171.75 & 48.14 \\
Minimum & 100.95 & 1 & 0.1 & 0.12 \\
Maximum & $37,987.60$ & 502 & $1,718.50$ & 470.25 \\
Number & 177 & 177 & 177 & 177 \\
\hline
\end{tabular}

Source: Chinese Exhibition Economic Report in 2018 and 2019

Regression analysis for 2018 and 2019 are presented in Table 3. Table 3 demonstrates impact of the number of exhibitions, total exhibition area changes, and composite index to county-level GDP. According to the R2 and adjusted R2 in the Table 3, the data in 2018 and 2019 were all greater than 0.75 and 0.77 respectively, which indicated that the data fit well with the two models. Table 3 shows that every 1 unit increase in the number of exhibits in 2018 had a positive impact on GDP of 6.6396 units, and every 1 unit increase in the composite index had a positive impact on GDP of 110.8028 units. In 2019, every 1 unit increase in the number of exhibitions also had a positive impact on GDP of 21.3495 units, and every 1 unit increase in the composite index had a positive impact on GDP of 182.3355 units.

However, an increase of 1 unit of total exhibition area in 2018 had a negative impact on GDP of 8.2022 units, and an increase of 1 unit of total exhibition area in 2019 had a negative impact on GDP of 30.3125 units. Under this regression analysis, because both the number of exhibitions and the composite index have a positive impact on GDP, most cities will increase their investment in exhibitions, either by increasing the number of exhibitions or the Composite Index.

Table 3. Regression analysis of urban exhibition competitiveness.

\begin{tabular}{ccc}
\hline Coefficients & $\mathbf{2 0 1 8}$ & $\mathbf{2 0 1 9}$ \\
\hline Intercept & $2,522.84$ & $2,206.70$ \\
(t-statistics) & $(9.7371)^{* *}$ & $(9.4681)^{* *}$ \\
Number of Exhibitions & 6.6396 & 21.3495 \\
& $(0.8278)$ & $(3.2477)^{* *}$ \\
Total Exhibition Area & -8.2022 & -30.3125 \\
& $(-1.5164)$ & $(-4.4120)^{* *}$ \\
Composite Index & 110.8028 & 182.3355 \\
\hline$R^{2}$ & $(6.3634)^{* *}$ & $(7.4837)^{* *}$ \\
$\bar{R}^{2}$ & 0.7553 & 0.7767 \\
\end{tabular}

Source: Chinese Exhibition Economic Report in 2018 and 2019

** Denote significant at $99 \%$ level

But regression analysis also shows that the total exhibition area will have a negative impact on GDP. Therefore, we cannot blindly increase the investment in the exhibition, especially the allocation of exhibition space must be in accordance with the characteristics of various types of cities and exhibition planning and adaptation. In addition, the model results also indicate that the Composite Index had the greatest impact on GDP. In 2018, the impact of the Composite Index on GDP was 16.6882 times the number of exhibitions and 13.5089 times the total exhibition area. In 2019, the impact of the Composite Index on GDP was 8.5405 times greater than the number of exhibitions and 6.0152 times greater than the total exhibition area. This means that in addition to the hard indicators of exhibition area and the number of exhibitions, we need to pay more attention to the composite index, that is, the exhibition of service characteristics and exhibition quality and other soft indicators, such as the inside spirit of historic culture, the driving power of professional products for extend market and the innovation of whole MICE activities like what this paper referred above. Each county or countylevel city have their own suitable types to apply, only if the inside potential is properly analyzed. Improving the overall index of the exhibition could better promote the development of national economy. 


\section{Conclusions and Suggestions}

\subsection{Give Full Play to the Advantages of Leading Industries and Cultivate Several Key Brands with Distinctive Features}

The development of the county MICE economy is always based on local leading industries, such as the wood carving exhibition, the hardware exhibition in Yongkang, and the Yiwu Fair. The exhibition economy should focus on its leading industries, insist on industry exhibition as the main body, promote industry exhibition by Industry, promote industry development by industry exhibition, strengthen main industry, make excellent characteristics, complement each other, and promote each other.

\subsection{Focus on First-class Standard and Promote the Internationalization of Well-known Local MICE Industry}

The internationalization development strategy around the Municipal Party Committee and the Municipal Government City must promote the degree of internationalization and the international influence of current brand exhibition by organizing and participating in well-known domestic and international exhibitions, inviting experts in the MICE industry to give lectures, encouraging the host of exhibitions to communicate and cooperate with well-known domestic and foreign convention and exhibition institutions, etc. It is also important to give full play to the platform advantages of trade associations, strengthen exchanges and resources with domestic and foreign trade associations, and increase the invitation to foreign exhibitors and buyers. At the same time, it is necessary to make full use of the domestic and foreign media, exhibitions, strengthen the publicity of the exhibition in this city, held in the exhibition along with international forum, foreign docking, and other activities to further create an international atmosphere.

\subsection{Focus on Regional Development and Introduce New Momentum for the Development of MICE}

Regional cooperation is becoming closer with the promotion of integration strategy. The development of county-level exhibition should grasp the integration development strategy and opportunities based on its own industry and market. They should take the initiative to link up with the surrounding cities, create new models and ideas for running exhibitions, and strive to set up a new batch of exhibitions through the introduction of market players with strong strength, sufficient experience, and abundant resources. It is also beneficial in conjunction with relevant industries to link up with industry associations. At the same time, introduction of several transferrable high-quality brand exhibition can be grafted from the perspective of benign complementarity with spillover effects. Optimal allocation of funds can be moderately guided toward some exhibitions for new, scale benefits are obvious, and sustainable prospects.

\subsection{Optimize the Exhibition Facilities and Plan New Exhibition Venues}

Exhibition venue is generally believed as the symbol to external publicity. It is necessary to plan and build new pavilions to meet the requirements of the economic development. As a county-level exhibition venue, it is not necessary to pursue the scale, grade, and appearance, but more consideration should be given to the practicality of the exhibition venue and the sense of experience. The venue should be in an area with relatively convenient transportation and logistics with the general area of the building within about 50,000 square meters (planning booth area should be 20,000 square meters and above). The surrounding layout, set of catering, accommodation, decoration design and other supporting facilities should be designed to expand the economic form and function of the exhibition.

\subsection{Optimize the Personnel Training and Establish a Multifunctional Exhibition Education System}

The development of exhibition industry requires the participation of many professionals. It is required to jointly settle in university and other well-known campus through the establishment of specialties, courses, and vocational training courses to explore the establishment of multifunctional exhibition education system for training professionals. On the policy of talent introduction, full consideration should be given to the particularity of the MICE industry and the standards of academic qualifications should be appropriately relaxed. At the same time, the exhibition industry association can be set up to play as a communication, resource gathering and data analysis platform. 


\subsection{Innovate the Model of Exhibition Industry and Accelerate the Development of the "Exhibition+" Economy}

Innovating the new form of exhibition must consider the reality and deepen the policies of "exhibition + trade, the exhibition + tourism, the exhibition + science and technology". Government should actively promote the integration of online and offline exhibition to create the market demand for online exhibition, getting rid of a variety of epidemic impact on the exhibition industry. The brand exhibitions sponsored by government should actively take the lead in using modern information technology, such as 5G, VR or AR, big data, and so on, to enhance the effects of exhibition and publicity through holding online exhibitions by holding cloud exhibitions, cloud docking and other activities. It's necessary to promote the interface between the physical market, online wholesale, and distributors for maintaining the position as an industrial base and a leading wholesale market.

\section{References}

1. Chen, Z. Y. (2019). County-level Exhibition Economy in China. China Conference \& Exhibition, 17: 82-84.

2. Luo, Q. J., Pang, J. W., \& Jin, W. M. (2011). An Empirical Study on the Economic Impacts of the Events with InputOutput Model: A Case Study of Canton Fair, China. Acta Geographica Sinica, 66(4): 487-503.

3. Ni, W. (2021). Exhibition Industry Helps County Economy under New Development Pattern. China Conference \& Exhibition, 1: 58-58.

4. Sui, J. Y. (2020). Research on the Impact of Festival Events on Urban Development. Business \& Economy, 10: 17-18.

5. Wang, Z. P. (2021). Deeply Tap the Development Needs of County MICE Economy Service Industry. China Conference \& Exhibition, 1: 59-59.

6. Zhang, Y. (2021). Research on the Development of County MICE Economy-Taking Haining City as an Example. Jiangnan Forum, 1: 43-44.

7. Zhao, B., \& Lu, J. (2017). A Study on the Countermeasures for the Development of Exhibition Economy in Hebei County. Journal of Shijiazhuang University, 19: 4-4.

(Editor: Linshan Zhou) 